\title{
Occurrence of Isarachnanthus (Cnidaria: Anthozoa: Ceriantharia) at Ascension Island: a test of hypothesis
}

\author{
SÉRGIO N. STAMPAR ${ }^{1}$ AND ANDRÉ C. MORANDINI ${ }^{2}$ \\ ${ }^{1}$ Faculdade de Ciências e Letras, UNESP-Univ Estadual Paulista, Assis, Departamento de Ciências Biológicas, Laboratório de \\ Biologia Aquática-LABIA, Avenida Dom Antonio, 2100, Assis, SP, 19806-900, Brazil, ${ }^{2}$ Universidade de São Paulo, Instituto de \\ Biociências, Departamento de Zoologia, Rua do Matão, trav. 14, 101, São Paulo, SP, 05508-090, Brazil
}

\begin{abstract}
A theory that an ancient population of Isarachnanthus from the eastern Atlantic originated the current species is discussed. Based on analysis of DNA barcoding and cnidome it was possible to identify some specimens from Ascension Island. These specimens were identified as Isarachnanthus maderensis, since the divergence of DNA barcoding was very small and the cnidome data agreed with published data. This material permitted an enhanced discussion about the origin of this population.
\end{abstract}

Keywords: biogeography, ocean currents, taxonomy, DNA barcoding

Submitted 7 November 2013; accepted 25 February 2014; first published online 3 April 2014

\section{INTRDDUCTION}

Ceriantharia taxonomy has been an issue since early studies in the 19th Century (e.g. Haime, 1854). Many of the characters show clear phenotypic plasticity, and almost nothing is known of this variation within this species (see van Beneden, 1924). Ceriantharia is a subclass within the class Anthozoa (Stampar et al., 2014). The use of DNA barcoding ( $5^{\prime}$ end of mtDNA cytochrome c oxidase I (COI)) methods in this class would be virtually impossible with the traditional approaches due to the low variability of mitochondrial DNA between species (Huang et al., 2008). However this profile is completely different in Ceriantharia compared to other class members. Mitochondrial DNA shows similar substitution rates to those found in other animal groups (e.g. Medusozoa and/or Bilaterian groups), thus the use of classical methods of DNA bar coding is quite possible (see more in Stampar et al., 2012, 2014).

Isarachnanthus Carlgren, 1924 is a genus of tube forming anemones within the order Ceriantharia which extend their tentacles only during the night (Stampar et al., 2012). Unlike many anthozoan taxa, some ceriantharian species have larval stages with long planktonic lifespans. These planktonic forms confounded earlier researchers who classified them as a group of jellyfish that belong to the other subphylum, Medusozoa (see Rodriguez et al., 2011). The genus Isarachnanthus consists of four species: I. bandanensis (Carlgren, 1924); I. maderensis (Johnson, 1861); I. nocturnus (den Hartog, 1977); and I. panamensis (Carlgren, 1924). A hypothesis about the origin of Pacific and West Atlantic species was raised by Stampar et al. (2012). The hypothesis stated that the ancestral species originated from the east

Corresponding author:

S.N. Stampar

Email: stampar@assis.unesp.br coast of the Atlantic. This could be verified with the unique occurrence of the species Isarachnanthus maderensis on the coast of Africa. However, the sub-Saharan African coast still remains a large gap in information, and large expeditions have only sampled in some parts of that region (e.g. Zibrowius \& Gili, 1990). We had access to some specimens of Isarachnanthus obtained from the oceanic Ascension Island (Figure 1). This record is important because it is an area with no information about Ceriantharia, and the island is under the influence of African ocean currents (see Peterson \& Stramma, 1991). The individuals were analysed for specific identification and the results discussed in relation to the data available from recent literature (Stampar et al., 2012).

\section{MATERIALS AND METHODS}

Ascension Island is an isolated volcanic island in equatorial waters of the South Atlantic Ocean, around $1600 \mathrm{~km}$ from the coast of Africa and $2250 \mathrm{~km}$ from the coast of South America. Two specimens of Isarachnanthus were collected around the island in September 2011 (MZUSP 001947/001948 and GENBANK KJ469802/KJ46980, respectively). The two specimens were preserved in formalin, but tentacle samples were preserved in ethanol. To study the specimens we followed the methods described by Stampar et al. $(2012,2014)$. The barcoding region (COI) was sequenced $(535-639 \mathrm{bp})$ and then compared with data provided by the same authors. Kimura's two-parameter model of base substitution was used to calculate genetic distances in MEGA5 software (Tamura et al., 2011). The maximum likelihood phylogenetic analysis was conducted via RAxML (500 replicates) (random accelerated maximum likelihood analysis) with general time reversible model and gamma rate heterogeneity (GTR + GAMMA) (Stamatakis et al., 2008). To evaluate nodal support and especially to detect if 


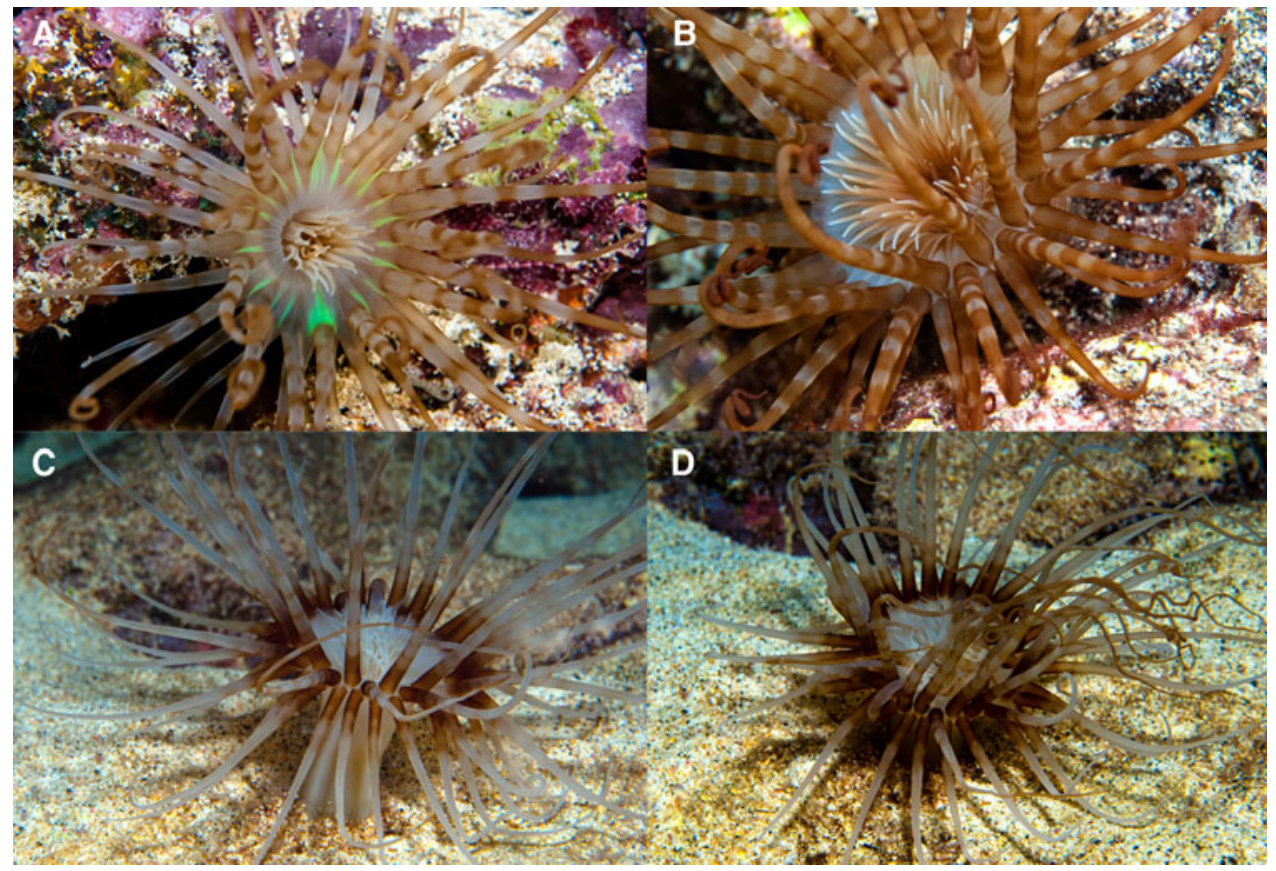

Fig. 1. In situ photographs of specimens of Isarachnanthus maderensis from Ascension Island: (A, B) oral view; (C, D) side view (images: Shallow Marine Surveys Group).

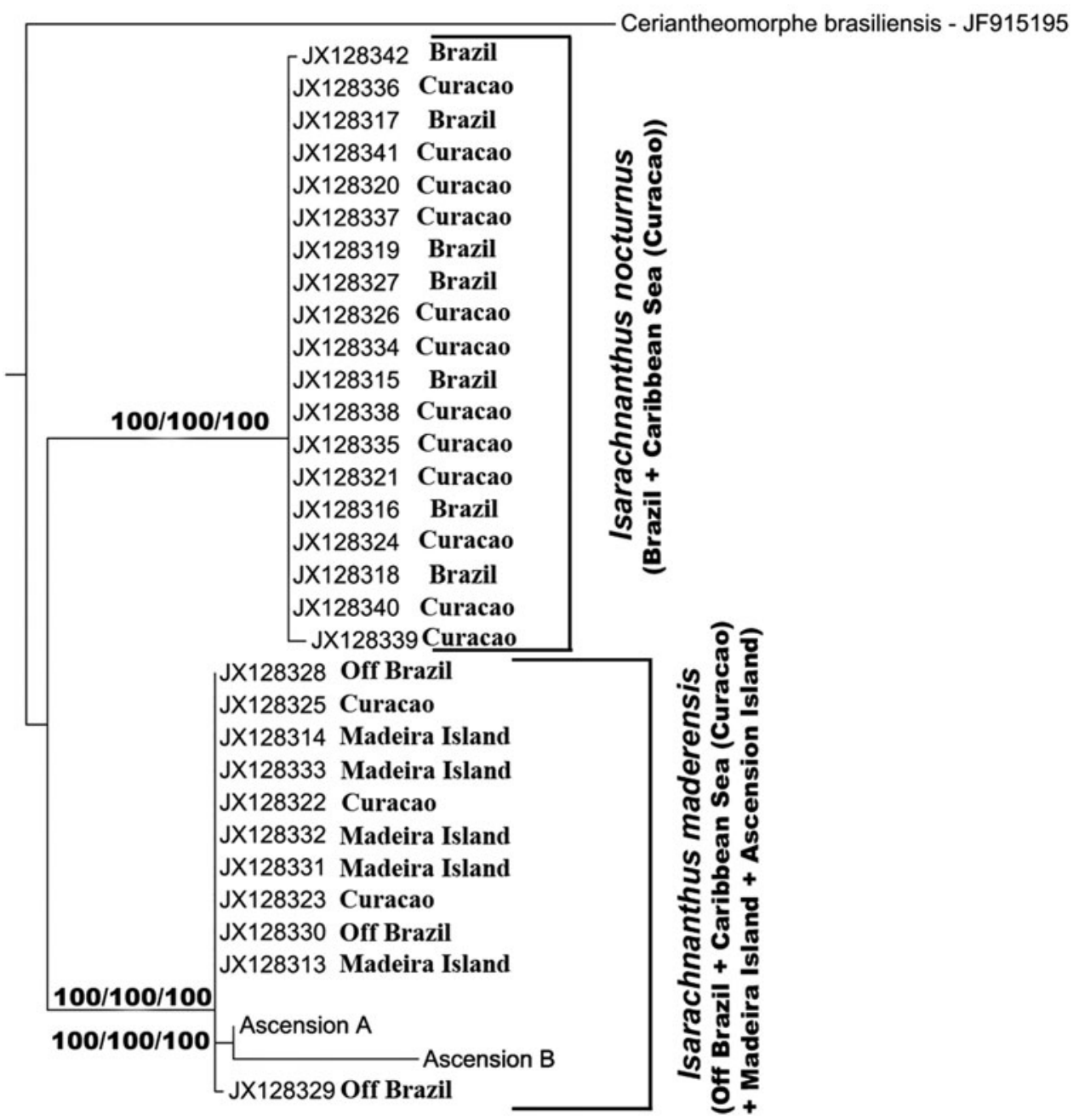

Fig. 2. Phylogenetic reconstruction (maximum likelihood) of the analysed specimens of Isarachnanthus using the mitochondrial marker COI. Numbers on the branches represent the estimated values of maximum likelihood (bootstrap)/SH-aLRT/aLRT. Ascension A and B are the specimens used for the analysis. 
Table 1. Cnidome of the studied specimens of Isarachnanthus maderensis from Ascension Island $(\mathrm{N}=2$ specimens $\times 30 \mathrm{cnidae})$.

\begin{tabular}{|c|c|}
\hline & Isarachnanthus maderensis $(\mathrm{N}=2 \times 30)$ \\
\hline \multicolumn{2}{|l|}{ Marginal tentacles } \\
\hline Atrich & $53.5(51.3-56) \times 7.4(6.3-8.1)$ \\
\hline Microb. B-mastigophore 1 & $15.10(11-17.1) \times 3.4(3-3.6)$ \\
\hline Microb. B-mastigophore 2 & $103.1(99.7-112) \times 25.5(24-28.8)$ \\
\hline Microb. B-mastigophore 2 & $52.20(50-58.5) \times 7.5(7.2-7.8)$ \\
\hline Microb. P-mastigophore & $38.12(36-42) \times 4.44(4.2-5.4)$ \\
\hline \multicolumn{2}{|l|}{ Labial tentacles } \\
\hline Atrich & $46.7(43.2-54) \times 7.14(6.6-8.2)$ \\
\hline Microb. B-mastigophore 1 & $37.7(35.5-39) \times 5.5(5.4-6.1)$ \\
\hline Microb. B-mastigophore 2 & $75.09(72-79.2) \times 15.8(14.3-16.9)$ \\
\hline Microb. B-mastigophore 2 & $53.58(48-59.4) \times 8.52(7.2-9.6)$ \\
\hline Microb. P-mastigophore & $33.66(30-38.4) \times 5.64(5.4-6)$ \\
\hline \multicolumn{2}{|l|}{ Stomodeum } \\
\hline Atrich & $48.10(43.2-52.8) \times 7.08(6.6-7.8)$ \\
\hline Microb. B-mastigophore 1 & $38.56(36-41.2) \times 5.70(5.4-6.65)$ \\
\hline Microb. B-mastigophore 2 & $74.15(73-77.8) \times 15(14.2-16)$ \\
\hline Microb. B-mastigophore 2 & $53.5(49-57) \times 8.52(7.2-9.6)$ \\
\hline Microb. P-mastigophore & $33.5(31-37) \times 5.5(4.6-6)$ \\
\hline \multicolumn{2}{|l|}{ Column } \\
\hline Atrich b & $35.5(34-40) \times 6.2(5.1-7.2)$ \\
\hline Pticocysts & $42.50(36-54) \times 11.25(9.6-12.6)$ \\
\hline Microb. B-mastigophore 1 & $22.8(20.4-25.2) \times 5.82(5.4-6.6)$ \\
\hline Microb. B-mastigophore 2 & $91.2(83-96) \times 22.25(18.9-25.2)$ \\
\hline Microb. B-mastigophore 2 & $78.3(72-82) \times 14.16(12-15.6)$ \\
\hline Microb. P-mastigophore & $22.8(20.4-25.2) \times 5.82(5.4-6.6)$ \\
\hline \multicolumn{2}{|l|}{ M-mesenteries (double cord) } \\
\hline Atrich & $36.24(31.2-42) \times 6.06(6-6.6)$ \\
\hline Microb. B-mastigophore 2 & $87.06(83.4-92.4) \times 23.82(21.6-27)$ \\
\hline Microb. B-mastigophore 2 & $77.94(72-84) \times 14.04(12.6-16.2)$ \\
\hline Microb. B-mastigophore 2 & $18.6(16.8-21) \times 6.9(6.6-7.8)$ \\
\hline Microb. P-mastigophore & $40.14(37.2-42.6) \times 6.18(6-6.6)$ \\
\hline \multicolumn{2}{|l|}{ B-mesenteries (simple cord) } \\
\hline Microb. B-mastigophore 1 & $20.80(18.4-24) \times 6.5(6-6.9)$ \\
\hline Microb. B-mastigophore 2 & $18.10(16.1-19.6) \times 6.6(6-7.9)$ \\
\hline \multicolumn{2}{|l|}{ Acontiods } \\
\hline Atrich & $41.23(39-47.1) \times 7.8(7.2-9)$ \\
\hline Microb. B-mastigophore 1 & $18.62(14.4-21) \times 4.62(3.6-5.4)$ \\
\hline Microb. B-mastigophore 1 & $19.20(17.8-21) \times 7.44(7.2-8.4)$ \\
\hline Microb. B-mastigophore 2 & $85.80(81-92.4) \times 25.5(24-27.6)$ \\
\hline
\end{tabular}

support values were positively/negatively biased, parametric (aLRT) and non-parametric (SH-aLRT) tests were applied (Anisimova \& Gascuel, 2006; Anisimova et al., 2011). Bootstrap values were computed on RAxML v.7.3.2 (500 pseudoreplicates, same parameters as the original phylogenetic analysis) and other statistical tests were calculated using PhyML v.3.0.1 (Guindon et al., 2010; Anisimova et al., 2011). At the same time the measurements of cnidae were compared with those of specimens from type locations of I. maderensis and I. nocturnus (as presented by Stampar et al., 2012).

\section{RESULTS}

Based on our analyses (morphology, cnidae and barcode) the specimens from Ascension Island belong to the species Isarachnanthus maderensis (Figure 1). The barcoding data show that the $\mathrm{K}_{2} \mathrm{P}$ divergence is $0.02-0.07 \%$ between specimens from Ascension Island and Madeira Island + Caribbean Sea + off Brazil (Rocas Atoll) but $9-9.6 \%$ in comparison with Brazilian + Caribbean Sea specimens of Isarachnanthus nocturnus. Maximum likelihood analyses shows that specimens from
Ascension Island are grouped with other specimens of Isarachnanthus maderensis with very consistent support values (Figure 2).

The cnidome data from Ascension Island specimens (Table 1) also confirm the similarities with specimens from Madeira Island and off Brazil (Rocas Atoll). The measurements of cnidae capsules of Ascension Island specimens are in the same range as Isarachnanthus maderensis. Furthermore, the most relevant data are the presence of three types of microbasic b-mastigophores on the stomodeum and the column, and the presence of microbasic p-mastigophores on the column. This pattern was only observed in specimens of Isarachnanthus maderensis (see data from Stampar et al., 2012).

\section{DISCUSSION}

The finding of Isarachnanthus maderensis specimens on Ascension Island provides good evidence in support of the hypothesis that the species Isarachnanthus nocturnus is restricted to the west coast of the Atlantic Ocean, with Isarachnanthus maderensis only occurring on the east coast in the South Atlantic Ocean, as proposed by Stampar et al. 


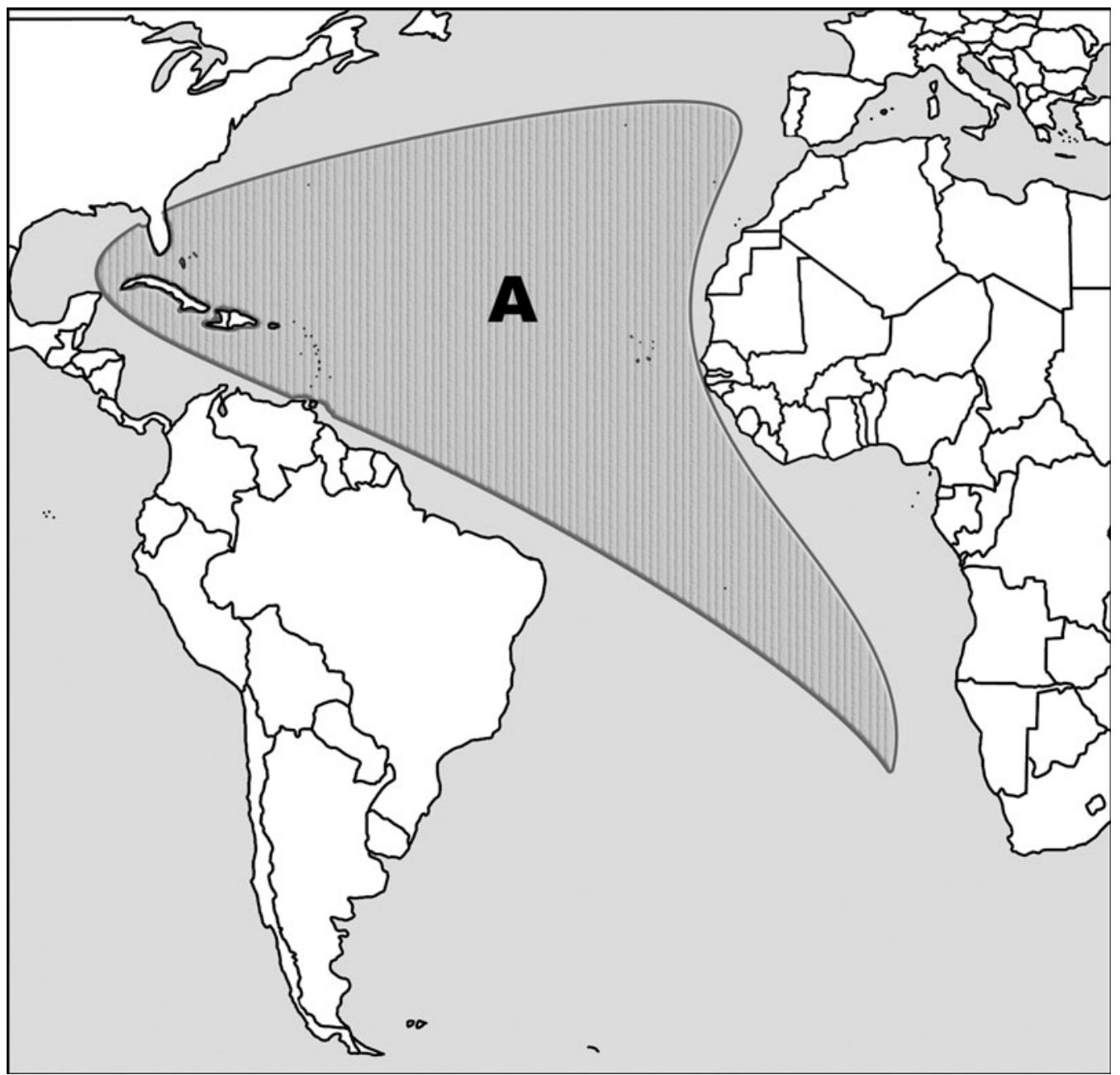

Fig. 3. Distribution pattern/area of Isarachnanthus maderensis in Atlantic Ocean (A).

(2012). Isarachnanthus specimens that are driven from the African coast by the South Equatorial Current must be exclusively 'maderensis' species (Figure 3). Ascension Island lies exactly under the influence of the South Equatorial Current (Dunbar, 1984) and probably receives a large amount of larvae derived from African coasts (McCartney et al., 2000). The genus addressed in this study presents planktonic larvae that can be carried by sea currents (Rodriguez et al., 2011). Unfortunately there are no data on the life cycle of this genus, except on the existence of a planktonic larva.

This study highlights the importance of investigating species distribution, especially considering remote islands. Geographical records on somewhat isolated places are necessary for a better understanding of evolutionary processes, particularly in testing theories already proposed, and in the subsequent understanding of marine populations. Furthermore, this study highlighted that the use of DNA barcoding in Ceriantharia, proposed by Stampar et al. $(2012,2014)$ is completely applicable and should be adopted by researchers.

\section{ACKNOWLEDGEMENTS}

We are grateful to the Shallow Marine Surveys Group and the South Atlantic Environmental Research Institute for organizing the expedition. We are also very grateful to the Ascension Island Government, the members of staff at the Conservation Centre and Ascension Island Dive Club for their cooperation, accommodation and hospitality. Finally we are grateful to British Forces South Atlantic Islands for their logistic support. We are also thankful to Paul Brickle and Peter Wirtz for comments on the text.

\section{FINANCIAL SUPPDRT}

The funding for this work came from a grant to the Shallow Marine Surveys Group from the Darwin Initiative (EIDCFo12). This work was also partly supported by grants 2012/01771 (S.N.S.), 2010/50174-7 (A.C.M.), São Paulo Research Foundation (FAPESP) and CAPES PROEX and CNPq 301039/2013-5 to A.C.M. and CNPq 481549/2102-9 to S.N.S. This study is a contribution of NP-BioMar, USP.

\section{REFERENCES}

Anisimova M. and Gascuel O. (2006) Approximate likelihood-ratio test for branches: a fast, accurate, and powerful alternative. Systematic Biology 55, 539-552. 
Anisimova M., Gil M., Dufayard J-F., Dessimoz C. and Gascuel O. (2011) Survey of branch support methods demonstrates accuracy, power, and robustness of fast likelihood-based approximation schemes. Systematic Biology 6o, 685-699.

Dunbar R. (1984) How animals know which way to go. New Scientist, 101 26-30.

Guindon S., Dufayard J.F., Lefort V., Anisimova M., Hordijk W. and Gascuel O. (2010) New algorithms and methods to estimate maximum-likelihood phylogenies: assessing the performance of PhyML 3.o. Systematic Biology 59, 307-321.

Haime J. (1854) Mémoire sur le cérianthe Cerianthus membranaceus. Annales des Sciences Naturelles 1, 341-389.

Huang D., Meier R., Todd P.A. and Chou L.M. (2008) Slow mitochondria COI sequence evolution at the base of the metazoan tree and its implications for DNA barcoding. Journal of Molecular Evolution 66, 167-174

McCartney M.A., Keller G. and Lessios H.A. (2000) Dispersal barriers in tropical oceans and speciation in Atlantic and eastern Pacific sea urchins of the genus Echinometra. Molecular Ecology 9, 1391-1400.

Peterson R.G. and Stramma L. (1991) Upper-level circulation in the South Atlantic Ocean. Progress in Oceanography 26, 1-73.

Rodriguez C.S., Marques A.C., Stampar S.N., Morandini A.C., Christiansen E., Genzano G. and Mianzan H. (2011) The taxonomic position of the pelagic 'staurozoan' Tessera gemmaria as a ceriantharian larva. Zootaxa 2971, 49-58.

Stamatakis A., Hoover P. and Rougemont J. (2008) A rapid bootstrap algorithm for the raxml web servers. Systematic Biology 57, 758-771.

Stampar S.N., Maronna M.M., Vermeij M.J.A., Silveira F.L.d. and Morandini A.C. (2012) Evolutionary diversification of banded tube-dwelling anemones (Cnidaria; Ceriantharia; Isarachnanthus) in the Atlantic Ocean. PLoS ONE 7, e41091. doi:10.1371/journal. pone.0041091.

Stampar S.N., Maronna M.M., Kitahara M.V., Reimer J.D. and Morandini A.C. (2014) Fast-evolving mitochondrial DNA in Ceriantharia: a reflection of Hexacorallia paraphyly? PLOS ONE 9, e86612. doi:10.1371/journal.pone.0o86612.

Tamura K., Peterson D., Peterson N., Stecher G., Nei M. and Kumar S. (2011) MEGA5: molecular evolutionary genetics analysis using maximum likelihood, evolutionary distance, and maximum parsimony methods. Molecular Biology and Evolution 28, 2731-2739.

van Beneden E. (1924) Travaux posthumes d' Edouard van Beneden sur les cérianthaires collationnés par Paul Cerfontaine. Archives de Biologie, hors serie 1-242.

and

Zibrowius H. and Gili J.M. (1990) Deep-water Scleractinia (Cnidaria: Anthozoa) from Namibia, South Africa and Walvis Ridge, southeastern Atlantic. Scientia Marina 54, 19-46.

\section{Correspondence should be addressed to:}

S.N. Stampar

Faculdade de Ciências e Letras

UNESP-Univ Estadual Paulista, Assis

Departamento de Ciências Biológicas Laboratório de Biologia Aquática-LABIA

Avenida Dom Antonio, 2100

Assis, SP, 19806-900, Brazil

email: stampar@assis.unesp.br 